International Journal of Business and Management Review

Vol.8, No.4, pp.11-38, July 2020

Published by ECRTD-UK

Print ISSN: 2052-6393(Print), Online ISSN: 2052-6407(Online)

\title{
EFFECT OF BANKING SECTOR REFORMS ON THE GROWTH OF MANUFACTURING SECTOR IN DEVELOPING ECONOMIES: A STUDY OF NIGERIA 1986-2018
}

\author{
Ali, Jude Igyo \\ Banking and finance Department, Nnamdi Azikiwe University Awka, Anambra State
}

\section{Clems Nwakoby (Ph.D)}

Academic Staff of the Banking and finance Department, Nnamdi Azikiwe University Awka, Anambra State Nigeria

\section{Okonkwo, Ikeotuonye Victor (Ph.D)}

Academic Staff of the Banking and finance Department, Nnamdi Azikiwe University Awka, Anambra State Nigeria

\section{Yua Henry}

Lecturer, Department of Banking and Finance, Nigerian Army College of Environmental Science and Technology, NASME Barracks Makurdi. Benue State, Nigeria.

\begin{abstract}
The study examined the effect of banking sector reforms on the growth of manufacturing sector in developing economies: a study of Nigeria. The specific objectives of this study is to investigate the relationship between aggregate credit to the manufacturing sectors (ACM), commercial banks' reserve requirement (CBR), commercial banks ' investment $(C B I)$, loan-to-deposits ratio $(L D R)$, lending rate $(L R)$, real effective exchange rate index (EXR) and manufacturing sector output growth (MGDP), anchored on financial liberalization theory and keynesian theory of finance and economic growth. The study used secondary data obtained from the publications of NBS and CBN and subjected them to Co-integrating and Serial Correlation CM Test to ascertain the long run and short run relationship between ACM, $C B R, C B I, L D R, L R$ and MGDP at 5\% level of significance. The findings shows that banking sector reforms did not have significant effect on growth of the manufacturing sectors for the period 1986 to 2018 in Nigeria. We recommend that a more structured reform programme with identifiable and specific objectives that prioritizes credit to the manufacturing sector should be promoted.
\end{abstract}

KEYWORDS: Banking reforms, manufacturing sector, aggregate credit, lending rate

\section{INTRODUCTION}

Industrial sector plays a fundamental role in a contemporary economy and has several dynamic rewards vital for economic revolution. To the advanced economies, the manufacturing sector is a leading sector in many respects. It is an avenue for increasing productivity related to import replacement and export expansion, creating foreign exchange earning capacity; and raising employment and per capita income which causes unique consumption patterns. Furthermore, it creates investment capital at a faster rate than any other sector of the economy while 
International Journal of Business and Management Review

Vol.8, No.4, pp.11-38, July 2020

Published by ECRTD-UK

Print ISSN: 2052-6393(Print), Online ISSN: 2052-6407(Online)

promoting wider and more effective linkages among different sectors (Yua, Upaa, Adiga \& Haruna, 2020).

In view of the foregoing, the Nigerian government has embarked on series of banking reforms starting with the establishment of Central Bank of Nigeria (CBN) in 1958 to coordinate banking sector activities with the aim of enhancing efficiency in financial service delivery, promoting investment, and ensuring efficacy in the resource allocation (Ali, 2015). The theoretical and conceptual foundation linking financial development and economic growth according to Owolabi, Olanrewaju and Okwu, (2013) can be traced back to the works of Bagehot (1873), Schumpeter (1912) and Lewis (1956). They clearly stressed the significance of banking sector in making available the required capital to fund economic activities especially the manufacturing sector which is regarded as the engine of economic growth and development (Owolabi, Olanrewaju \& Okwu, 2013). Thus, the general consensus that manufacturing sector have the aptitude of creating a path way to development that would provide a progressive trajectory than other economic activities cannot be overemphasized considering that manufactured goods are the network hubs that tend to connect to many other activities, enabling food security and economic sustainability. It is also a well-known fact that, the multiplier effect of manufacturing sectors on the other sectors of the economy is believed to be transformative and growth-driven (Owolabi,Olanrewaju \& Okwu, 2013).

Developed economies of the world such as China, America and Japan have devoted huge financial and human capital resources in developing parameters such as technology and financial systems that support the manufacturing sector of their various economies. The main reasons advanced for the failure of so many resource-rich countries of Sub-Saharan Africa to transform their natural wealth into a self-sustaining growth process is because of their lack of investment in manufacturing sector (Frank \& Rotimi, 2016). The countries that are able to harness the potentials of the foregoing sectors have achieved great industrial development and economic growth. (Sanusi, 2010; Anyanwu, 2010; Owolabi, Olanrewaju \& Okwu, 2013).

Industrialization constitutes a veritable channel of attaining the superior and desirable conception and goals of improved quality of life for the populace. In any economy, one or more sectors serve as a prime mover, moving the rest of the economy forward. Therefore, the role of engine of growth or leading sector has usually been played by manufacturing sectors under the industrialization process (Yua, Iorember, \& Kumshin, 2018). Consequently, the development of the manufacturing sector represents the deliberate and sustained application and combination of suitable technology, finance, management techniques and other resources to move the economy from the traditional low level of production to a more automated and efficient system of mass production of goods.

The centrality of the manufacturing sector to economic growth and development cannot be over stated. This is because the role of these sectors in the conversion of raw products to finished goods through the industrialization process appears to be the main hope of developing economies such as Nigeria with a large population and labour force. In recognition of the important role of these sectors, successive governments in Nigeria have continued to articulate policy measures and programme to achieve growth incentives and adequate finance in that, the central goal of government policy has been to foster growth in the manufacturing sector of the economy (Yua, Iorember \& Kumshin, 2018). The role of deposit money banks' financial 
International Journal of Business and Management Review

Vol.8, No.4, pp.11-38, July 2020

Published by ECRTD-UK

Print ISSN: 2052-6393(Print), Online ISSN: 2052-6407(Online)

intermediation process in the efficient and effective performance of the manufacturing sectors cannot be overemphasized. A better mobilization and prudent use of financial resources is required. But, a well-functioning and efficient financial sector with sophisticated institutions and regulatory systems to foster economic growth and development through private initiatives and new technologies seems to be inadequate in the Nigeria's economic system.

The Nigerian financial system and the banking sector in particular have been characterized with series of reforms. These reforms are intended to ensure a formidable banking system that allows free flow and efficient allocation of the scarce financial resources to attract the much needed development which the manufacturing sector is at the core of it. The underlining purpose of these reforms according to Soludo (2004), Lemo, (2005) and Sanusi (2012) is to enable the banking sector to develop the required capacity to support various sectors for economic development by efficiently performing its functions as the head of financial intermediaries. This crucial role makes it pertinent for the banking sector to be regulated regularly to ensure efficiency, stimulating financial innovation while creating confidence in the system. These various reforms in the Nigerian banking system have made remarkable changes over the years, in terms of the number of institutions, ownership structure, as well as depth and breadth of operations (Olokoyo, 2013).

The era of free market economy, which started in 1986, brought a major policy shift. Prior to the adoption of market economy, which resulted to the introduction of Structural Adjustment Programme (SAP) in early 1986, the Nigerian economy was characterized by excessive government control of production, financial intermediation processes and foreign trade variables via the administrative determination of interest rates, prices and exchange rates. However, the country's passion with this strategy progressively lost force, principally because it failed to deliver its most vital quest of sustained economic growth and development. This resulted to an adverse economic performance. SAP was introduced to reduce the adverse effects, which the interventionist policies had on economic performance. In conformity with the objectives of SAP, financial sector reforms were aimed at enhancing the efficiency of the intermediary process through greater reliance on the market forces to control market activities. The main component of this included liberalizing the interest rates, promoting competition in the market for financial services, reducing control on credits, strengthening the regulatory institutions as well as promoting the growth and deepening of the financial sector (Udah, 2011).

To further boost the domestic economy, major economic and structural reforms were introduced in 2003 under a comprehensive economic blue print (the National Economic Empowerment and Development Strategy (NEEDS). One of the objectives of NEEDS was to build and promote comprehensive and healthy financial system that will support economic development. As entrenched in NEEDS, the main reforms include the adoption of universal banking from 2001; recapitalization of banks to a minimum paid up capital of 25 billion naira; issuance of new code of corporate governance for the financial sector, the project Alpha under Sanusi, the recent directive on payment of dividends by tier II banks and exchange rate management regime.

The reforms in the banking sector are based on a conviction that their gains will be accrued through expenses reduction, increased market power and reduced earnings volatility, economies of scale which will create a vibrant banking system. However, according to Ali 
International Journal of Business and Management Review

Vol.8, No.4, pp.11-38, July 2020

Published by ECRTD-UK

Print ISSN: 2052-6393(Print), Online ISSN: 2052-6407(Online)

(2015) the character of the sort of reforms that has characterized the Nigerian banking industry creates doubt about its prospects of realizing efficiency gains. While these reforms no doubt have benefits, what is less clear is the effect of these reforms on the operating efficiency of the banks (Lemo, 2005) to contribute effectively to the growth of manufacturing sector. In view of this observation, certain issues arose on the need or otherwise of these imposed reforms exercises; that will the boost in market power create monopoly which in theory increases price (bank interest rates) and reduce output (financial intermediation)? What seemingly impedes effective allocation of financial resources to the different sectors of the economy to spur the much needed development of a growing economy such as Nigeria?

The foregoing concern then becomes a source of worry as to whether or not the Nigerian banking sector is really repositioned through the various reforms to contribute or mobilize and allocate the huge scarce financial resources effectively and efficiently to manufacturing sector of the Nigerian economy. Also, in spite of the financial sector liberalizations, the growing concern is that the Nigerian banking industry remains shallow and performs well below average when compared with developed economies such as the USA, Germany and Japan; and the newly industrialized countries of China, Malaysia and India Ali (2015) and Hamid, (2012). Thus, can the submissions of (Ali, 2015 \& Hamid, 2012) who opine that the financial systems in Nigeria lack depth, and they only serve a small proportion of the geometrically-growing population at a relatively high cost be substantiated?

Banking sector reforms embarked upon at different times in Nigeria seeks to achieve the objectives of financial liberalization, efficiency in resource allocation, expansion of savings mobilization base with the expectation that it will encourage investment and drive the much desired economic growth in general (Anyanwu, 2010). However, the apparent nonperformance of the manufacturing sector in the wake of the foregoing concerted efforts with germane objectives of repositioning the key parameters that are supposedly expected to enhance growth of the real sector and the economy in general is worrisome. This worry emanates from the inability of the reforms especially in the banking sector to have caused the Nigerian banking sector to drive the necessary growth of the manufacturing sectors in Nigeria. This has poised a great apprehension on the significance of the reforms introduced in the Nigerian banking system to the growth of the manufacturing sector.

The foregoing stated challenges of abysmal performance bedevilling the manufacturing sector also bring to mind the dichotomy that exist both in theoretical and empirical literatures as regards the relationship between finance, reforms and growth of the manufacturing sector. The available extant theories indicate mixed arguments on the relationship between banking sector reforms and growth of manufacturing sector. Some theorist argue that financial resources lead to economic growth vis-vis manufacturing sector hence financial repression carried through reforms impede growth which is a major characteristic of developing economies (Mackinon, 1973; Shaw, 1973; Olanrewaju, Aremo \& Aiyegbusi, 2015), while others view economic growth ( manufacturing sector in particular) as one of the factors that influence supply of financial resources, indicating that growth of the manufacturing sector ensure financial sector deepening and that financial system needs to be controlled to ensure efficiency hence the need for regular reforms (Roubini, \& Sala-i-Martin, 1992 \& Balogun, 2007). The result of empirical studies also showed lack of unanimity in their findings. These calls for more research in this area to ascertain the effect of banking sector reforms on the growth of manufacturing sectors 
International Journal of Business and Management Review

Vol.8, No.4, pp.11-38, July 2020

Published by ECRTD-UK

Print ISSN: 2052-6393(Print), Online ISSN: 2052-6407(Online)

in a developing economy such as Nigeria. This study will therefore provide a critical insight in these areas while validating or disagreeing with the foregoing theoretical postulations.

Consequently, there are questions that are always on fore-front: have the various reforms orchestrated in the Nigerian banking sector repositioned it to effectively advance service to the manufacturing sector in order to stimulate growth?; is there any causal link between banking sector reforms and growth of manufacturing sector? This research identified a number of research gaps in the course of reviewing existing related literature. A range of studies reviewed in this study examined the aggregated effect of banking sector reforms on manufacturing sectors or economic growth in general (Owolabi, Olanrewaju \& Okwu, 2013; Lawrence \& Ikechukwu, 2015; Ebele \& Iorember, 2016). In the wake of this, the study utilized disaggregated data as done in some few studies with specific variables in line with the reform clusters to ascertain the definite effect of each of the reform periods on the growth of manufacturing sectors. The study also examined the relationship between the total numbers of commercial bank branches as a proxy for banking structure reforms which is an improvement over other studies as it is has not been examined by other studies.

\section{THEORETICAL FRAMEWORK AND EMPIRICAL LITERATURE}

\section{Theoretical Framework}

Theoretically, there has been a consensus on the relationship between banking sector reforms and manufacturing sector growth. This is explained by the financial liberalization theory and keynesian theory of finance and economic growth, The study is anchored on the two forgoing theories as explained below.

\section{Financial Liberalization Theory}

Schumpeter (1912) cited by Olanrenwaju, Aremo, and Aiyegbuisi (2015) in his theoretical link between financial development and economic growth opines that the services provided by financial intermediaries are the essential drivers for innovation and growth. His argument according to Olanrenwaju, Aremo, and Aiyegbuisi (2015) was later formalized by McKinnon (1973) and Shaw (1973). The McKinnon-Shaw leveraging on the work of Schumpeter (1912) as indicated by Olanrenwaju, Aremo, and Aiyegbuisi (2015), propounded the financial liberalization thesis which postulates that government restrictions on the operations of the financial system through reforms, such as interest rate ceiling, direct credit programs and high reserve requirements may hinder financial deepening, and this may in turn affect the quality and quantity of investments and, hence, have a significant negative effect on economic growth. Therefore, the McKinnon-Shaw financial repression paradigm implies that a poorly functioning financial and heavily controlled system retard economic growth.

McKinnon (1973) and Shaw (1973) paradigm seems to be the first systematic attempt at taking into account some of the specific characteristics that impair the performance of financial system in developing countries (Olanrenwaju, Aremo \& Aiyegbuisi, 2015). They argued that financial sector in most developing economies is repressed by series of government interventions that have negative effect on financial deepening and economic growth. The repression takes different forms, such as imposition of mandatory minimum capital, ceiling of interest rate, imposition of trade restriction as well as imposition of larger reserves and liquidity 
International Journal of Business and Management Review

Vol.8, No.4, pp.11-38, July 2020

Published by ECRTD-UK

Print ISSN: 2052-6393(Print), Online ISSN: 2052-6407(Online)

requirements. In addition to these, there are restrictions that constrained banks to engage in certain types of lending and prohibit them from acquiring some financial assets.

Central to the argument of Mckinnon and Shaw is the idea of financial sector liberalization.

The theory further argued that, the notion of economic growth and development can be accomplished by effective financial system through effective capital allocation. However, the activities of the financial sector in both developed and developing economies are not devoid of government interventions which are against the postulations or the submission of Makinnon and Shaw. They argued that saving and investment are discouraged through repressed financial sector as what could be obtained in a competitive market. Financial intercessors in this system function at low capacity thereby hindering saving, investment and development in the economy.

Recent studies by King and Levine (1993), Adegite, (2005) Dada, (2015); Aiyetatan and Aremo (2015); Enang and Francis (2016) among others also support the postulations of Makinnon and Shaw, stating that reticent financial system regulation stamps down growth, explicating that interest ceiling, liquidity ratio requirement, capital control, restrictions in market entry into the financial sector, credit ceilings or restrictions on direction of credit allocation and government ownership or domination of banks are polices that cause financial repression. Both McKinnon and Shaw advocated that financial liberalization through financial deregulation is the antidote for a financial repressive policy and enhanced economic of developing countries.

However, Robinson (1952), Ali (2015) among others, disagreeing with the foregoing submissions, suggested that a financial system should not automatically adopt laissez-faire economic policy that is devoid of government regulations which according to the foregoing school of thought create financial repression due to the negative implication of repressed financial system on economic growth. They argued that financial liberalization creates crises in most developing countries because of the external shocks it usually exert on the economy. Also, removing all public financial regulations may lead to market imperfection, asymmetric information and thereby hindering a favorable financial development environment. They suggested regulations that ensure market competition as well as prudential regulation and supervision as an alternative to a financial repressive regime. Overall the McKinnon and Shaw financial repression hypothesis suggests the critical role of interest rate liberalisation as a significant factor to economic growth. The hypothesis signals the crucial role of a liberalized economy along with other control variables in driving growth in an economy of which manufacturing and agricultural sectors represent an important component.

Thus, the financial liberalization thesis attributed the pitiable performance of investment and growth in developing countries to interest rate ceiling, high reserve requirements and quantitative restrictions in credit allocation. According to this theory, the restrictions were sources of financial repression, and the main symptoms are low savings, credit rationing and low investment in that economy. Thus the need for financial liberalization which frees financial market from any intervention and allows the market forces of demand and supply to determine the allocation of credit in an efficient manner (Ighosewe \& Akpokerere, 2015). The theory therefore, is against active participation of government in economic activity and argues that the 
International Journal of Business and Management Review

Vol.8, No.4, pp.11-38, July 2020

Published by ECRTD-UK

Print ISSN: 2052-6393(Print), Online ISSN: 2052-6407(Online)

role of government, if any, should be limited to the maintenance of law and order and the creation of relevant institutions for the efficient functioning of the free market system.

This research work will be anchored on this theory since it postulations predominantly explained the relationship between the variables under study which is the basis for empirical analysis of this research work. The foregoing justification is important considering that, the financial sector is central to mobilization and allocation of financial resources through intermediaries from surplus economic units to deficit units. A well-developed financial system enhances investment by identifying and funding good business opportunities, mobilizing savings, a function that result in a more efficient allocation of resources, rapid accumulation of physical and human capital, and faster technological progress, which in turn result to economic growth (Campbell \& Asaleye, 2016).

\section{Keynesian Theory of Finance and Economic Growth}

The theory suggests that financial system (instruments, markets, and institutions) arise to mitigate (or reduce) the impact of information and transaction costs; influencing savings rate, investment decisions, technological innovations, long-run growth and development through its activities. The theory explains further that the financial system ameliorates market frictions through its basic functions which taken together affect growth and development through two channels: capital accumulation and technological innovations. In this regard market frictions (information and transaction costs) motivate the emergence of financial market and intermediaries that provide the basic functions which affect growth and development through capital accumulation and technological development (Levine, 1997). Considering capital accumulation, the theory emphasizes a steady-state per capita growth as being generated using capital externalities or capital goods produced with constant returns to scale but without the use of non-reproducible factors. Thus, the functions performed by financial system affect steady state growth by influencing the savings rate or through reallocation of savings among different capital producing technologies while on technological innovation, the theory emphasis new production process and goods. Here, the financial functions affect steady-state growth by altering the rate of technological innovation.

\subsection{Nigeria Banking Sector Reforms}

Banking was introduced into Nigeria in 1892 with the establishment of the African Banking Corporation which was subsequently acquired by the Bank of British West Africa in 1894. Nonetheless, the banking system remained rudimentary with economic activities carried out either by barter or use of commodity money. According to Adekanye (1986), there was no monetary system in Nigeria before 1912 when the West African Currency Board (WACB) was established. He added that the West African Currency Board introduced the West African Pound to replace the variety of circulating media of exchange in these territories. WACB was however only established to issue West African Pounds and to ensure convertibility of the West African Pounds into English Pounds. It therefore could not control the demand for or supply of money. In 1917, Barclays Bank was established. These two banks had a virtual monopoly on banking business up until the end of the Second World War (Emmanuel, 2007).

The Nigerian economy, having evolved under the British rule and subsequent independence, necessitated the need to establish a workable framework to regulate the banking system and also serve as a banker to government, hence the strings of banking sector reforms starting with the establishment of the Central Bank of Nigeria (CBN) in 1958. The CBN Act of 1958 
International Journal of Business and Management Review

Vol.8, No.4, pp.11-38, July 2020

Published by ECRTD-UK

Print ISSN: 2052-6393(Print), Online ISSN: 2052-6407(Online)

established the Central Bank of Nigeria and saddled it with the responsibility of promoting monetary stability and sound financial structure in Nigeria. The major aims of the Central Bank Monetary policy were price stability, output growth, full employment and equilibrium in the balance of payment. Thus in the early years of Central Bank of Nigeria, operations was essentially that of reliance on direct tools of monetary control, such as credits (aggregate and selective), special deposits, interest rate, and issuance of stabilization securities. It was a highly regulated financial environment, a non-market operating strategy to directly control the banks aggregate credit to the economy. Entry into banking business was restricted and public sector owned banks dominated the industry. Thereafter came the deregulation period of 1986 . The neo-liberal era witnessed the dismantling of the prolonged regime of economic and financial controls to make way for increased reliance on market forces in 1986. This was embedded into the Structural Adjustment Program (SAP). The major reforms in this era included deregulation of interest rates and exchange rate, removal of preferred sector credit allocation and free entry into banking business subject to satisfaction of various other conditions for obtaining a banking license (Evelyn, 2010). Though the deregulation reforms in Nigeria started in the fourth quarter of 1986 with the setting up of a foreign exchange market in September 1986, the reforms pertaining to the banking industry proper did not commence until January 1987 (Ikhide \& Alawode, 2001; Asogwa, 2005; Adegbite, 2005).

According to Adegbite (2005) the first measure reform in the banking sector was the deregulation of the rate of interest both on loans and on deposits. Banks became free to charge whatever rates of interest they desired on their different products based on the forces of demand and supply. As interest rates were being deregulated government also brought out new rules for setting up of banks and issuing of licenses. The new rules made entry into the banking system much easier than previously. Adegbite (2005) further posited that the immediate response of the system to these two policies was a sudden up-surge in the number of banks from 56 (Merchant and Commercial bank) in 1986, the figure rose to 109 by 1990 and 120 by 1992. In the wake of reforms in the financial sector, the exchange rate was also not unaffected. In the exchange sector, the exchange rate was freed from government administration and a market for auctioning forex was set up. At first there were two windows, the official window where forex was sourced for government imports and official transactions at administratively controlled rates, and the non-official window where licensed foreign exchange dealers (usually banks) bid for foreign exchange on behalf of their clients, and the foreign exchange rate was determined by forces of demand and supply (Adegbite, 1994 as cited by Adegbite, 2005). By 1987, however, the two foreign exchange windows were merged to form one door called the foreign Exchange Market. By 1988, in order to absorb the parallel foreign exchange market into the official market and cater for the needs of small users of forex government granted licenses for bureau de change operators. As government was granting licenses to the Bureau De Change operators in the trade and exchange sector, it was also relaxing the rule that had hitherto forbidden banks from taking up equity position in firms (i.e. non-financial enterprises) while at the same time granting them permission to engage in insurance brokerage.

In the face of a much greater number of financial institutions especially banks, than the country had ever had, the government thought it expedient to protect depositors by setting up a deposit insurance scheme. Hence, the Nigerian Deposit Insurance Corporation (NDIC) was established in 1988 and started operation in January 1989. The CBN deployed some of its staff to start off the corporation. The NDIC is supposed to ensure financial stability and provide a healthy 
International Journal of Business and Management Review

Vol.8, No.4, pp.11-38, July 2020

Published by ECRTD-UK

Print ISSN: 2052-6393(Print), Online ISSN: 2052-6407(Online)

banking platform for the economy. By 1994 another reform measure was introduced. Hitherto, banks in Nigeria had not been paying interest on demand deposits otherwise known as current account, but now they were granted permission to do so. The cash reserve ratio which before the reforms had been virtually stagnant was revised, to begin to work as an indirect instrument of credit control and granting of loans on the strength of foreign exchange held in foreign accounts was prohibited. All government deposits held by the commercial and merchant banks were withdrawn, so that the banks could function without undue government interference.

In 1993 the Open Market Operations (OMO) as an indirect instrument of monetary control was introduced. The first discount house took off in 1993 known as Associated Discount House, subsequently others followed, and by 2003 there were about five discount houses. The discount houses intermediate between the Central Bank and the other banks, off loading government treasury securities from the $\mathrm{CBN}$ and auctioning same to the banks. Where the banks cannot pick-up all of the treasury securities the discount houses warehouse them. The reforms introduced also affected the capital base of banks as the capital funds adequacy ratio was reviewed. The capital adequacy ratio was moved from 1:12 to 1:10. The purpose of adjusting the capital adequacy ratio was to ensure that the banks have sufficient capital to absorb shocks in times of operational losses, and also to ensure that shareholders in banks have sufficient stake in the system to do a thorough oversight job of bank management. Hence the prudential Guideline was released by the CBN in 1990. As this was going on other reform measures to deepen and expand the financial system were also going on. Special institutions were in 1989/90 created, this include - the People's Bank, the Community Banks, finance companies and Leasing companies.

Regarding the capital adequacy issue, government through the $\mathrm{CBN}$, introduced a riskweighted measure of capital adequacy. The regulation identified five risk-weights of $0 \%, 10 \%$, $20 \%, 50 \%$ and $100 \%$. The banks were told to maintain capital funds of at least $7.26 \%$ of total risk weighted assets. The reform also required that at least $50 \%$ of a bank's capital must take the form of core or primary capital i.e. equity plus reserves. In 1990 the equity capital of commercial banks was raised from $\$ 20$ million to $\$ 50$ million, while that of the Merchant banks rose from 12 million to $\$ 40$ million. The 1990 Prudential Guideline directed banks to make adequate provisions for bad and doubtful debt. Banks were required to stop accruing interest on non-performing loans, while interest that had already accrued on such accounts should be discountenanced and not to be recognized as income. Something that used to be in the system before deregulation was reintroduced. This is the stabilization securities. Stabilization securities are CBN's debt instrument made compulsory for banks to purchase and they are non-transferable and non-negotiable. The Stabilization securities carry higher yield than treasury bills.

In 1991 two new decrees were put in place to enhance the powers of the regulatory and supervisory authorities of the financial system to enable them manage the reform packages effectively and efficiently. The CBN Decree 24 of 1991 and the, Banks and Other Financial Institution Decree, 25 of 1991. The new banking sector regulatory reforms gave the CBN power to issue banking licenses and to revoke them. It gave the CBN power to apply any type of measure to handle ailing financial system. Also by 1991 some of the reform measure of 1987 were reversed, a cap was replaced on interest rates standing at $21 \%$ for lending rates and $13.5 \%$ for deposit rates. Also a maximum interest rate spread was specified at 4\%. By 1992 
International Journal of Business and Management Review

Vol.8, No.4, pp.11-38, July 2020

Published by ECRTD-UK

Print ISSN: 2052-6393(Print), Online ISSN: 2052-6407(Online)

government divested itself from the seven banks where it had $60 \%$ equity holding in line with the new private sector driven development and privatization. It was believed a full private sector owned banks would be more efficiently managed and hence more effective in its operations and have improved performance. By 1997 additional capital market reforms were introduced, while by 1999, fully foreign owned banks were given licenses to operate. By the year 2000 foreign currency deposits had become institutionalized while by 2001 government went the whole hog and introduced universal banking, such that a bank can be a single-point unit for an investor, as a bank with a universal license can carry out merchant banking functions, commercial banking functions, insurance functions, and also deal in issue of securities (a capital market function). At the wake of universal banking, government introduced a new capital of 1 billion for each category of banks, and raised it by the year 2002 to 2 billion.

By 2004 July the CBN announced a new capital base for banks of $\$ 25$ billion. This was however in the wake of many weaknesses, defects and challenges that were still inherent in the banking sector which led to the 2004 reforms. They comprise low capital base, overdependence on public sector deposits and foreign exchange trading increased number of unsound banks and weak corporate governance, poor asset quality, with the neglect of small and medium scale enterprises (SMSE), among others (Soludo, 2005).

The banking sector reforms of 2004, which placed emphasis on recapitalization, have been generally described as banking sector consolidation in Nigeria. The main objective of the 2004 reform was to consolidate, deepen and enhance financial sector stability and competitiveness. Towards this end, CBN launched a 13point reform agenda for the banking sector on July 6 , 2004 with the main objective of recapitalizing the banks to meet a new minimum capital base of $\$ 25$ billion. Other aims of the reform according to Soludo (2004) include (1) Consolidation of banking institution through mergers and acquisition: (2) adoption of a risk-focused and rule based regulatory framework, (3) adoption of zero-tolerance in the regulatory framework especially in the area of data/information rendition and reporting, (4) strict enforcement of the contingency planning and for systemic banking distress, (5) the establishment of an Asset Management Company as an important element of distress resolutions, (6) the automation process for the rendition of reforms by Banks and other financial institutions through the enhanced Financial Analysis and Surveillance System (e-FASS), (7) the promotion of the enforcement of dormant laws, especially those relating to the issuance of dud cheques, and the law relating to the vicarious liabilities of the Board members of banks in cases of failing by the banks; and (8) closer collaboration with the Economic and Financial Crime Commission (EFCC) in the establishment of the Nigerian Financial Intelligence Unit (FIU); and (9) the enforcement of the anti-money laundering and other economic crime measures (CBN, 2004). These far reaching reforms were adjudged to exhibit the required pedigree surmount the perceived inherent challenges in the Nigerian banking sector.

With the assumption of office, the then Governor of CBN, Mallam Sanusi Lamido Sanusi further identified weaknesses in the Nigerian banking system warranting another set of reforms. The reforms postulated by Sanusi popularly called the post-consolidation period (2008-2011) witnessed the interplay between the adverse effects of the 2007-2009 Global Financial Crisis. Considering the foregoing, the CBN developed a blueprint for reforming the Nigerian banking industry built around four pillars chronicled as "The Project Alpha Initiative". The reforms 
International Journal of Business and Management Review

Vol.8, No.4, pp.11-38, July 2020

Published by ECRTD-UK

Print ISSN: 2052-6393(Print), Online ISSN: 2052-6407(Online)

were aimed at removing the inherent weaknesses and fragmentation of the financial system, integrating the various ad-hoc and piecemeal reforms and unleashing of the huge potential of the economy. This culminated into the initiation of the Expanded Discount Window (EDW) was a financial support facility through which the CBN provides liquidity to the ailing banks, for short-term fund needs purposes. Also, in a wake of preventing the perceived calamity more critical steps were taken to resolve the challenges which include:- (1) Macro-economic instability caused by the banking sector (2) Lack of investor and consumer sophistication (3) Major failure in corporate governance in the banking sector (4) Inadequate disclosure and transparency about the financial position of banks. (5) Critical gaps in regulatory framework and regulations (6) Uneven supervision and enforcement (7) Unstructured governance and management process at the CBN/weaknesses within the CBN (8) Weaknesses in the business environment in the country (Okonkwo \& Bankoli , 2016).

The measure pillars of the 2009/2010 Banking Reform, as rightly captioned by Okonkwo and Bankoli (2016), were aimed at achieving far reaching results some of which include:

\section{Enhancing the Quality of Banks}

In achieving this objective, the $\mathrm{CBN}$ intend to initiate as part programme to enhance the operations and quality of Nigerian banks. These programme initiatives will include: data quality, enforcement, governance, risk management and financial crime. These initiatives will be structured in such a manner that the banks do most of the work to imbibe new behaviours in the industry, with the CBN playing a cross - industry programme management role. Individual must be held responsible for their actions.

\section{Establishing Financial Stability}

The key features of this pillar centre around strengthening the financial stability committee (FSC) within the CBN, establishment of a hybrid monetary policy and macro-prudential rules, development of directional economic policy and counter-cyclical fiscal policies by the government and further development of capital markets as alternative to bank funding. Nigeria can only improve its economic performance if it deals squarely with two fundamental issues, which are; Volatility and instability caused by over-reliance on oil and sub-optional management of oil revenue, and ability of the non-oil real sector to productively absorb investment and debt.

\section{Enhancing Healthy Financial Sector Evolution}

This include repositioning banking industry structure, banking infrastructure such as credit bearers and registrars, cost structure of banks and role of the informal sector. The creation of the Asset management Corporation (AMC) will provide the first step towards the resolutions of non-performing loan problem in banks and eventually facilitate further consolidation.

\section{Ensuring that Financial Sector Contributes to the Real Sector}

Development financial institutions set up for specific purposes such as housing finance, trade finance, urban development have not fulfilled their mandates. Many successful emerging economics have witnessed proactive government actions to ensure that the financial sector contribute to the real sector. Nigeria can learn from countries with successful track records in creating financial accommodation for economic growth through initiatives such as development finance, foreign direct investment, venture capital and public private partnerships. The CBN is in a good position to advocate economic development in Nigeria. 
International Journal of Business and Management Review

Vol.8, No.4, pp.11-38, July 2020

Published by ECRTD-UK

Print ISSN: 2052-6393(Print), Online ISSN: 2052-6407(Online)

The reform process of this era essentially began with the joint audit of the banks (in batches) by the Central Bank of Nigeria (CBN) and National Deposit Insurance Corporation (NDIC) which produced startling revelation. The following were the major highlights of the 2009 banking reform:

i. The removal of CEOS and executive Directors of banks found wanting and prosecution of the CEOs of five affected banks.

ii. Injection of bailout fund ( 420 billion) to stabilize affected banks and another N200 billion to other banks.

iii. $\quad$ Publication of names of outstanding debtors of affected banks.

iv. The provision of fund by the government to reflate the economy.

v. Implementation of tenures for CEOs in the banking sector and the approval of all potential CEOs by the CBN.

The outcome of the reform programmes includes the following:-

1. The reform programmes forced many large borrowers with non-performing loans, who did not have any intentions to pay back their loans to scramble to pay back or make payment arrangements; thereby reducing the number of non-performing loans and the need for longer loan provisions for most of the banks.

2. Banks with questionable uncollectible and non-performing loans were forced to set up proper loan loss provision, which revealed the true financial health of most of the banks in Nigeria.

3. CBN's decision to set up an Asset Management corporation gave financial institutions the optimism that some percentage of their bad assets will be absorbed by the corporation. Also, investors had renewed confidence that absorption of some bank bad assets will free up capital to banks which will eventually trickle down to investors and the capital market. Although the $\mathrm{AMC}$ is not a panacea to most of the problems with the banking sector, the notion of its implementation helped spur the bullish resurgence that the Nigerian stock Exchange has experienced since the beginning of 2010.

4. Many foreign investors who had taken a pause from the Nigeria capital markets started returning as they are comfortable with the transparency that the CBN reform has ushered.

5. CEO's who did not act as shareholders custodians, and who thought that the banks were their personal properties were given the boot, dispelling the illusions by most of the former CEO's that they owned the banks and were not accountable to shareholders.

Below is the summary of the various reform regimes in Nigeria:

\section{Manufacturing Sector Growth}

Manufacturing sector as a sub-sector of the real sector denotes the productions of goods and services through utilization of raw materials and other factors of production such as labour force, land and capital by means of production process (Ebele \& Iorember, 2016). They further posit that in developed economies, the manufacturing sector is a conspicuous sector in every facet. It provides an opportunity for amassing productivity related to import replacement and export expansion, building foreign exchange earning capacity, per capita income and checking the rate of unemployment. Furthermore, it creates a multiplier effect on investment capital at a faster rate than any other sector of the economy while promoting wider and more effective linkages among different sectors through value chain creation (Adeyinka, Daniel \& Olukotun, 2015: Yua, 2017).

Campbell and Asaleye (2016) opine that the manufacturing sector is one of the vital sectors of an economy that stimulates sustainable growth and development also with the ability of 
International Journal of Business and Management Review

Vol.8, No.4, pp.11-38, July 2020

Published by ECRTD-UK

Print ISSN: 2052-6393(Print), Online ISSN: 2052-6407(Online)

creating the much needed jobs for both developed and especially developing economies. For instance, Akinmulegun and Oluwole (2014) observe that, the developed economies like China, the manufacturing sector generated an average of over fourteen million jobs in 2014 and up to about 10.1per cent of total employment world over. In addition, China had experienced a fast industrialization process that sustains the nation's economic growth for eras as a result of prominence devoted to the manufacturing sector as the main driver of economic growth. Evidence from other developed economies indicates that rapid growth in the manufacturing sector has been accompanied by higher productivity and profitability of individual manufacturing companies and high GDP figures in general (Campbell \& Asaleye, 2016). Therefore, the optimum performance of the manufacturing sector of emerging economies is imperative to surmounting challenges of huge deficit in employment, high import as against export expansion, volatility of foreign exchange earning capacity, low per capita income and a crawling economic growth in general.

\section{Restructuring/Refinancing to the Manufacturing Sector/SMEs}

In a bid to unlock the credit market, the CBN provided $\$ 500$ billion out of which $\$ 200$ billion is for re-financing/re-structuring of banks 'existing loan portfolios to the manufacturing sector and SMEs. The investment is in the form of debenture stock to be issued by the Bank of Industry (BOI). The main objective of the fund is to fast-track the development of the manufacturing sector by improving access to credit by manufacturers as well as improving the financial position of the DMBs. The category of facilities under the fund include long-term loans for acquisition of plant and machinery, refinancing of existing loans, resuscitation of ailing industries, working capital and refinancing of existing lease. The loan amount for a single obligor is the maximum of 1 billion in respect of re-financing/restructuring with an interest rate of 7.0 per cent payable on quarterly basis. All the 24 banks in the country as well as Development Finance Institutions (DFIs) excluding the Bank of Industry (BOI) are to participate in the fund.

\section{Effect of Banking Sector Reforms on Manufacturing Sector in Nigeria}

Prior to the oil boom of the 1970's, manufacturing contributed approximately $10 \%$ to Nigeria's aggregate output. Thereafter, increased revenues from oil led to growth deceleration in its contribution to GDP. The recession caused by the fall in oil prices in the early 1980's triggered policy attention to stimulate the manufacturing sector, with steel production gaining prime focus. Before this time, the Nigerian Enterprises Promotion Decrees of 1972 and 1977 had switched the majority firm ownership from foreign to Nigerian, prohibiting foreign capital inflows. The lack of affordability of imported goods, combined with the absence of foreign capital and technology, encouraged domestic production of basic commodities such as soap and salt. This era also witnessed vast increases in importation of intermediary inputs and thus the expansion of assembly based industry (Frank \& Rotimi, 2016).

In 1987 import bans on raw materials were imposed under the World Bank sponsored Structural Adjustment Programmes (SAP) to encourage import substitution. With intermediary input manufacturers were able to produce competitively again, and there were fewer plant closures. This, combined with the Privatisation and Commercialisation Act of 1988, encouraged to some extent manufacturing activities, with manufacturing output rising from \$11.7 billion to N40.8 billion from 1986 to 1990, respectively (Frank \&Rotimi, 2016). 
International Journal of Business and Management Review

Vol.8, No.4, pp.11-38, July 2020

Published by ECRTD-UK

Print ISSN: 2052-6393(Print), Online ISSN: 2052-6407(Online)

Throughout the period from early 1990 to 2000, Nigeria heavy reliance on oil revenue altered the country's export and production structure against diffused-natural resources, like manufacturing and agriculture. A few industries, such as beverages, textiles, cements and tobaccos kept the manufacturing sector afloat, but were often observed to operate well below their installed capacities considering the massive infrastructural deficit that has bedeviled the Nigerian economy. Thus, firms lacked scale-efficiency in production and were not exportorientated, which led competitive companies to relocate their factories abroad (Omolara\&Asaleye, 2016). It is worthy of note that, many factors have contributed to the variation in manufacturing sector share through time, and these factors cover the vulnerability of manufacturing to global economic pressures, as well as the impact of policy changes and others driven by poor infrastructural and institutional frameworks.

Further evidence from the National Bureau of Statistics indicate that the manufacturing sector accounts ten per cent of total GDP annually and about 12 per cent of the labor force in the formal sector (NBS, 2010). Accordingly, the statistics available revealed that the Nigerian economy revealed strong GDP growth from the period of 2004 to 2013 that averaged over 8per cent. This means that the size of the Nigerian economy is 170 per cent times larger today than at the beginning of the decade. It is however clear from this statistic that the structure of the Nigerian economy has changed significantly experiencing steady growth rate. However, the growth rate has not improved the measure macroeconomic indicators. Unemployment rate in Nigeria continues to increase as a result of inability of the private and public sectors to create job opportunities to cope with the increasing labor force. Available statistics indicate that as the population increases, there are difficulties for both young and old to get gainful employment. Despite the increased economic growth that the country witnessed in decades, the unemployment rate has worsened for a long period of time. Evidencing none performance of the manufacturing sector as it is adjudged to possess the capacity to create massive jobs considering the value chain potentials of the sub-sector.

The manufacturing sub-sector capacity utilization fell from $75 \%$ in 1980 to $42.7 \%$ in 1986 and to $39.0 \%$ in 1990 . By 1992, the sector capacity utilization rose to $40.4 \%$ and in 1995 collapsed to $29.3 \%$. In the same vein, growth rate of manufacturing rose from $23.6 \%$ in 1965 to $77 \%$ in 1975. But falling drastically to only $6.6 \%$ in 1980 . The only rise that exceeded $10 \%$ since then was recorded at $20.5 \%$ growth rate in 1985 (CBN, 2000). By 1993, it has fallen to $4.2 \%$ in 1994, it was recorded 5\%. In general, the industrial sector as a whole grew by $5.2 \%$ in 1980 to 1986 period, and also fell to $1.02 \%$ in 1996 to $0.72 \%$ in 1997 . By 2005 when the consolidation period fully kicked off the trend of Capacity utilization was $52.8 \%$ maintaining a downward declined to $48.0 \%$ up to 2009 . Similarly, direct manufacturing employment declined over the years. 2,752,832 people were engaged by manufacturing sector in 2001, 1,043,982 in 2005 then dropped to 1,026,305 in 2008 (Anyanwu, 2010). The overall performance of the manufacturing sector has been below expectation as a supposed engine of growth of the economy.

Considering the foregoing, the general over view of the manufacturing sub-sector in Nigeria from the available statistics has had a mixed performance over the years, owing to the fluctuations in its contribution to the country's Gross Domestic product (GDP). In 1960, manufacturing share of the Nigeria's GDP was $4.8 \%$ rising to $6.9 \%$ in 1965 and to $7.2 \%$ in 1970 , the manufacturing sector' contribution to the GDP stood at $8.3 \%$ in 1987 and started declining in 1993 from $7.2 \%$ to $6.0 \%$ in 2000 (CBN, 2003). 
The credit extended to the manufacturing sector by DMBs for the periods, 1981 to 2017 showed an upward trend. In 1981, the Banks' credits provided to the manufacturing sector, was paltry $\mathrm{N} 2.7 \mathrm{~b}$, rising to 7 7.4b 1n 1990. From 2001 to 2010, 2014 and 2016, the credits extended to manufacturing sector moved from $\$ 206.9 \mathrm{~b}$ to $\mathrm{N} 987.6 \mathrm{~b}$ and $\$ 5857.5 \mathrm{~b}$ and 2,215.7tr naira respectively. However, the volume and value of the credit extended to the manufacturing subsector clearly indicate inability of DMBs' advances to effective salvage the problem of this sector considering the enormous capital needs in the areas of acquisition of heavy equipments, modern technology and human capital development in the wake increased advances to the sector (CBN, 2003).

The significance of manufacturing activities on the economy of a nation cannot be argued. In developed economies, for instance, they account for a substantial proportion of total economic activities. In Nigeria, the subsector is responsible for about $10 \%$ of total GDP annually. In terms of employment generation, manufacturing activities account for about $12 \%$ of the total force in the formal sector of the nation economy performance (Bada, 2017).

In advanced economies, the manufacturing sector is a leading sector in different aspect; it is an avenue of increasing the productivity related to import replacement and expansion, creating foreign exchange earnings and per capital income, which causes unique consumptions patterns (Nzotta, 2014; Yua, Iorember \& Kumshin 2018). However, the effectiveness of manufacturing companies is dependence on the availability of financial resources, infrastructural and human capital development to meet up with the demands, this bring about the need for the banking sector in Nigeria to allocate a substantial amount in developing the subsector of the economy. In Nigeria, the manufacturing sector having been a measure beneficiary of banking services revealing that it is not unaffected by the reforms measures that are undertaken in the financial system and banking sector in particular. The various reforms in the Nigerian banking sector brought about far reaching polices decision with both positive and negative effect on the Nigerian manufacturing sector. For instance; the foreign exchange restrictions placed on fortyone items by Central Bank of Nigeria has affected the operations in the various sectors of the economy. Yua (2017) posit that several manufacturing companies had closed down as a result of the restriction order. These have led to loss of the job in the industries and increased the staggering rate of unemployment. The non-availability of production inputs, high interest rates on credit facilities available to the sectors, poor power-supply, policy inconsistency, poor patronage of locally manufactured products, poor supporting infrastructures, among others are the challenges confronting Nigerian manufacturers.

Frank and Rotimi (2016) posit that inadequate infrastructure, the devaluation of the naira and seemingly inability of the Nigerian banking sector to fund huge projects have further shrunk down capacity utilization and have led to high cost of production. Owing to these factors, the domestic economy witnessed an unprecedented closure of factories and production plants, this assertion of weakening economy, more sectors were being affected by the recession and the profile of unemployment kept rising. According to Aiyetan and Aremo (2015) despite all attempts in developing the manufacturing sector, the situations of manufacturing sector in Nigeria revealed that manufacturing sector has not improved appreciably. The available statistics have show that the number of registered manufacturing firms with the Manufacturers' Association of Nigeria (MAN) dropped from 4850 in the 1980s to 2000 in 2010. 
Considering the enormous responsibility to reposition the Nigerian economy where huge financial resources are required to provide the needed infrastructure that will cause development not just in the manufacturing sector, the banking sector needs to be periodically reformed to meet up the challenges. Thus, various reforms in the Nigerian banking sector have attempted to address the issues of capital formation by creating depositors' confidence which invariably boost banking sector liquidity, enhancing the capital base of banks and ensuring corporate governance codes are been adhered to which will exert significant positive effect on the bank asset quality of the banking sector among others. The foregoing measures no doubt impact positively on the Nigerian manufacturing sector in Nigeria.

\section{Empirical Literature}

Significant body of empirical research has examined the links between banking sector reforms and growth of manufacturing sector in Nigeria. Using different statistical methods and data applied have found diverse results and effect across different economies. For instance, Frank and Rotimi (2016) study the impact of domestic financial reform on manufacturing sector performance in Nigeria using time series from 1981 to 2014. Result showed that, the coefficient of financial reform is positive, indicating that financial sector policies can directly support real economy growth, though not significant in specified parsimonious error correction model. Bank credits were both positive and significant signifying that the availability of finance can have favorable and immediate impact on real sector growth. Also natural resource rent was positive and highly significant. Both human capital and prime lending rate were positive and significant, while domestic investment was not significant. They finally opined that given the low level of industrial sector growth in Nigeria, there is need to speed up financial sector reform to enhance intermediating efficiency, promote robust institutional quality and prudent use of scarce resources.

Yua, Upaa, Adiga \& Haruna, (2020) examined commercial banks' credit and manufacturing sector performance in emerging economies: evidence from Nigeria. The specific objectives of the study were to investigate the effect of commercial bank loans and advances (CBLA), commercial banks' lending rates (CBLR), inflation (INFL) and aggregate savings (ASAV)on manufacturing performance in the emerging economies. The study was anchored on loan pricing theory and the neo-classical theory of interest rate. The study used secondary data obtained from the Central Bank of Nigeria statistical bulletin and used for the analysis. The variables for the study were tested for unit root using the Augmented Dickey Fuller test and the test of Johansen cointegration within the framework of vector error correction was applied to test for the short-run and long-run effect. The findings of the study revealed that commercial banks' credit had significant effect on the manufacturing sector performance. The study concluded that commercial banks' credit enhanced manufacturing performance in emerging economies. This paper also suggests some measures in order to boost employment and manufacturing performance in Nigeria.

Sunday (2018) examined the impact of bank credits on manufacturing sector outputs in the deregulated Nigerian economy for a period of 1986-2016. The data collected were analysed using Autoregressive Distributed Lag (ARDL) models. It was found out that banks credits contributed positively to manufacturing sector output in both short-run and long-run. For causality relationship, EXR, SAV and LR granger cause manufacturing sector outputs. Hence, 
International Journal of Business and Management Review

Vol.8, No.4, pp.11-38, July 2020

Published by ECRTD-UK

Print ISSN: 2052-6393(Print), Online ISSN: 2052-6407(Online)

the main determinants of MSO are EXR, SAV and LR. The study recommended amongst other things, that the Central Bank and other monetary authorities alike should make policy that will lead to increase in bank credit to the manufacturing sector.

Lucky and Bruno (2018) examines the effect of financial reforms on banking sector efficiency in Nigeria from 1986- 2016. The study employed exchange rate, interest rate and liquidity variables. Using OLS regression the findings indicate that financial reform targets have significantly affected banking sector efficiency in Nigeria in the long run. The study recommends that the regulatory and supervisory framework should be strengthened while interest rate policy should be made to stimulate savings through high real deposit rate and lending rate so as to promote financial deepening and thus banking efficiency.

Bernhard (2017) investigated banking sector reforms and economic growth using time series data from 1970 to 2013 for the Nigerian economy. Autoregressive Distributed Lags (ARDL) Bounds test was applied for the specific determination of the long and short-run relationships between banking sector reforms and economic growth. The research finds that the interest rate margin is more significant than other variables in the model in explaining the banking sector reforms and economic growth. Banking sector credit to the private sector was negative and statistically insignificant to economic growth in Nigeria. This means that the size of the banking sector does not enhance economic growth. Meanwhile, inflation is negatively and statistically significant to economic growth. The duration of banking sector reforms should be defined and strictly adhered to, irrespective changes in the political administration of the country.

Lawal, (2016) examined the effect of exchange rate fluctuations on manufacturing sector output in Nigeria from 1986 to 2014. Data for the study was sourced from (CBN) statistical Bulletin and World Development Indicators (WDI) on manufacturing output, Consumer Price Index (CPI), Government Capital Expenditure (GCE), Real Effective Exchange Rate (EXC) and analyzed through the multiple regression analysis using Autoregressive Distribution Lag (ARDL). The ARDL result showed that exchange rate fluctuations have long run and short run relationship insignificant effect on the manufacturing sector output. Also that government expenditure has a positive relationship on manufacturing sector output but not significant. The study recommended that government should implement the policies on export strategies to encourage exports and discourage imports in order to achieve a favourable balance of payment; government should encourage the use of domestic materials in production in order to encourage international competitiveness and also increase expenditures on economic services such as manufacturing so as to increase their output.

Adesanya and Obademi (2016) study the effect of banking reforms on the economic growth of Nigeria. Using time series data from 1994 to 2014 with the aid of ordinary least square they found that banking sector developments that were experienced in Nigeria`s economy at one point or the other had significant effect on the activities of the economy. However, according to them, this does not imply that the reforms in the banking sector are solely responsible for the sector being better off. The study recommended an improvement in financial intermediation, monetary policy intervention and consistent regulations as necessary ingredients for stimulating investment, raising productive capacity and fostering economic growth. 
Ikeora, Igbodika and Andabai, (2016) evaluate the relationship between banking sector reforms and performance of Nigerian economy using Secondary data spanning from 19982013 with the aid of Vector Error Correction Model (VECM), the result showed that there is a long-run equilibrium relationship between banking sector reforms and performance of Nigerian economy. Also, the coefficient of determination indicates that about $55 \%$ of variation in the performance of Nigerian economy can be explained by changes in banking sector reforms variables. The study also found that there is causality between banking sector reforms and performance of Nigerian economy. The study then sued monetary authorities to be more proactive in bank supervision and pursue the supervisory framework based on prudence and professionalism. Also that, monetary and fiscal policy should be properly aligned towards stimulating and deepening the economy while ensuring that banks effectively managed their resources by focusing on risk management and corporate governance tenets.

Ebele and Iorember (2016) x-ray the effect of commercial bank credit on the manufacturing sector output in Nigeria from 1980 to 2015 using Cochrane-Orcutt method. Five variables of manufacturing sector output, inflation rate, interest rate, loans and advances and broad money supply were used for the study. They found that, inflation rate and interest rate have negative effect on manufacturing sector output while loans/advances and broad money supply have positive effect with manufacturing sector output in Nigeria. The study therefore recommended formulation and implementation of policies that aim at reducing both inflation and interest rates on one hand and on the other hand, increasing loans and advances as well as broad money supply so as to enhance improvement in the sector's output.

Simon-Oke, and Jolaosho, (2016) investigate the impact of financial reforms on industrial productivity growth in Nigeria. Using a time series data between the period of 1986 to 2013 with the aid of vector auto-regression analysis, impulse-response and variance decomposition, the study established that the various financial sector reforms put in place since the introduction of the Structural Adjustment Programme (SAP) in Nigeria have not significantly brought about the needed improvement on the level of industrial productivity growth in the country. They however laid credence to the to the essence of the financial reform operations to specifically target the industrial sector of the economy through a growth engendering reform policy capable of ensuring a sizeable and economically viable lending rates regimes. The provision of expansionary grants

Olanrewaju, Aremo, and Aiyegbusi (2015) investigate the effect of banking sector reforms on the output of manufacturing sector of the Nigerian economy from 1970 to 2011. Using cointegration analysis and Error Correction Mechanism (ECM), the result showed that the effects of Bank assets, Lending rate, Exchange rate and real rate of interest on manufacturing output were positively significant although with very low impact. On the other hand, the financial deepening and interest rate spread negatively and significantly impacted on the output growth of manufacturing sector in Nigeria. The study submits that, the effect of banking sector reforms on the output growth of manufacturing sector were significantly low in the Nigerian economy within the study period.

Dada, (2015) examine the effect of financial sector reform on the growth of manufacturing sector. Utilizing manufacturing output and financial sector reforms variables including credit to manufacturing sector, real rate of interest to manufacturing sector, market capitalization and 
International Journal of Business and Management Review

Vol.8, No.4, pp.11-38, July 2020

Published by ECRTD-UK

Print ISSN: 2052-6393(Print), Online ISSN: 2052-6407(Online)

total deposit from 2001 to 2011 with the aid of co-integration and granger-causality techniques. The result indicates that financial sector reform had a direct effect on the growth of the manufacturing sector in Nigeria. He called on the government to create a more conducive and enabling environment by improving on infrastructures, security as well as protecting indigenous industries in order to build-up the manufacturing sector of the economy.

Aiyetan and Aremo (2015) employ Vector Autoregression (VAR) analysis to test whether or not financial sector variables stimulate the growth of output in manufacturing sector of the Nigerian economy, by maintaining interactions with some key macroeconomic variables in the Nigerian economy using annual data from 1986 to 2012. The study also applied unit root and Johansen cointegration tests to examine the behaviour of the macro data. The result suggests that relaxing financial development constraints and deepening the financial sector are crucial to boosting themanufacturing output growth in Nigeria.The study therefore recommended that the banking sector should not serve only the government and influential borrowers, thereby leaving genuine private sector borrowers with little or no credit. Also that, the government should encourage banks to increase their lending to the private sector, especially small and medium enterprises that are ready to invest in the real sector of the economy to enhance output growth.

\section{Model Specification and Methodology}

The study adopted the model by Owolabi, Olanrewaju and Okwu (2015), stated thus:

MGDPt $=f(\mathrm{BFt}, \mathrm{LCt}, \mathrm{At})$

This model is slightly modified to accommodate the researcher's variables structure as follows: MGDP $=f(\mathrm{BSR})$

Where: MGDP which is the dependent variable is the GDP component of manufacturing sector while BSR which is the independent variable stands for banking sector reforms indices. However, since banking reforms are carried out to ensure deepening of key indicators in the sector, the reforms affect banking sector variables that will be used as proxy for the reforms. Accordingly, the structural models for this study are expressed in the equations below:

MGDPt $=f(\mathrm{ACM}, \mathrm{CBR}, \mathrm{LDR}, \mathrm{CBI}, \mathrm{LR}, \mathrm{EXR})$

Thus the explicit model of equation 3 and 4 can be stated as:

$\mathrm{MGDPt}=(\mathrm{ACM}+\mathrm{CBR}+\mathrm{LDR}+\mathrm{CBI}+\mathrm{LR}+\mathrm{EXR}-$

Furthermore, the stochastic form of the model is expressed as:

$\mathrm{MGDPt}=\beta 0+\beta_{1} \mathrm{ACAt}+\beta_{2} \mathrm{CBRt}+\beta_{3} \mathrm{LDR} \mathrm{t}+\beta_{4} \mathrm{CBIt}+\beta_{5} \mathrm{LR} \mathrm{t}+\beta_{6} \mathrm{EXRt}+\varepsilon \mathrm{t}$

Nevertheless, considering the recommendation of McClearly and Hay (1980) the variables in the models will be transformed into a logarithm form in order to remedy the heterogeneity of variance to avoid porous results. Thus the log function gives us:

$\log M G D P=\beta 0+\log \beta_{1} A C M t+\log \beta_{2} C B R t+\log \beta_{3} L D R t+\log \beta_{4} C B I t+\log \beta_{5} L R t+$

$$
\log \beta_{6} \mathrm{EXRt}+\varepsilon \mathrm{t}
$$

In the equations above $\beta 0, \beta_{1}, \beta_{2}, \beta_{3}, \beta_{4}, \beta_{5} \beta_{6}$ are parameters to be estimated while $\varepsilon t$ is the error term.

The meaning of the abbreviations used in the model is stated below:

MGDP: $\quad$ Manufacturing sector output growth.

ACM: Aggregate credit to the manufacturing sectors as a proxy for Credit Operations Reforms.

CBR: Commercial Banks' reserve requirement as a Capitalization and Capital Adequacy Reforms proxy by commercial banks reserve requirement with the central bank. 
CBI: Commercial Banks' Investment as proxy for corporate governance reforms

LDR: Loan-to-deposits ratio as a proxy for Asset Quality Management Reforms.

LR: $\quad$ Lending rate as a proxy for Liquidity Management Reforms.

EXR: $\quad$ Real effective Exchange Rate Index.

et: $\quad$ error term

\section{A priori Expectations}

The a priori expectation of the model in the above equations is that ACM, CBR, LDR and TCBB in the model should have a positive relationship with the dependent variables because an increase in stated foregoing variables should cause an increase in the growth of manufacturing sectors. On the other hand, LR and EXR is expected to have an inverse relationship with the output growth of manufacturing sectors in that, increases in LR and EXR will potentially reduces the value and availability of investable funds thereby leading to a reduction in the level of output. However, the intercept values $(\beta 0)$ could either be positive or negative. $\beta 0$ is constant and $\beta 1$ to $\beta 5$ are the coefficients, while $\varepsilon t$ is the stochastic error term. The summary of the apriori expectation is that $\beta_{1}, \beta_{2}, \beta_{3}$ and $\beta_{4}>0$ while $\beta_{5}$ and $\beta_{6}<0$. On the other hand $\beta_{0} \geq 0$.

\section{RESULTS AND FINDINGS}

\section{Unit Root Tests}

Unit root test is carried out to determine if the variables are stationary and if not, to determine their order of integration (i.e. number of times they are to be differenced to achieve stationarity).

Table 4.1: Stationarity Tests at Levels

\begin{tabular}{|c|c|c|c|c|}
\hline \multirow[b]{2}{*}{ Variables } & \multicolumn{3}{|l|}{ ADF Tests at Levels } & \multirow[b]{2}{*}{$\begin{array}{l}\text { Order } \\
\text { Integration }\end{array}$} \\
\hline & $\begin{array}{ll}\text { Absolute } & \text { Test } \\
\text { Statistic } & \text { with } \\
\text { intercept } & \\
\end{array}$ & $\begin{array}{l}\text { Absolute } \\
\text { Critical } \\
\text { Values@ 5\% } \\
\end{array}$ & Remark & \\
\hline AGDP & 2.6716 & 2.9571 & $\begin{array}{l}\text { has unit } \\
\text { root }\end{array}$ & \\
\hline ACA & 1.2205 & 2.9571 & $\begin{array}{l}\text { has unit } \\
\text { root }\end{array}$ & \\
\hline ACM & 1.7911 & 2.9604 & $\begin{array}{l}\text { has unit } \\
\text { root }\end{array}$ & \\
\hline CBI & 0.3031 & 2.9604 & $\begin{array}{l}\text { has unit } \\
\text { root }\end{array}$ & \\
\hline CBR & 1.0002 & 2.9810 & $\begin{array}{l}\text { has unit } \\
\text { root }\end{array}$ & \\
\hline LR & 4.3348 & 2.9571 & no unit root & $I(0)$ \\
\hline LDR & 4.1992 & 2.9640 & no unit root & $I(0)$ \\
\hline EXR & 1.9342 & 2.9571 & $\begin{array}{l}\text { has unit } \\
\text { root }\end{array}$ & \\
\hline
\end{tabular}

Source: Researcher's Computation 
Print ISSN: 2052-6393(Print), Online ISSN: 2052-6407(Online)

The unit roots test result at levels is reported in Table 4.1. The ADF test rejected the null hypothesis of the presence of unit root at levels for commercial bank lending rate (CLR) and loan-to-deposit ratio (LDR). So the CLR and LDR series were integrated of order one, that is I(1). manufacturing sector performance (MGDP), aggregate credit to aggregate credit to the manufacturing sector (ACM), commercial banks' reserve requirement (CBR), commercial banks' investment (CBI), loan-to-deposits ratio (LDR), commercial banks lending rate (LR) and real effective exchange rate index (EXR). 
Print ISSN: 2052-6393(Print), Online ISSN: 2052-6407(Online)

Table 4.2: Stationarity Tests at First Differences

\begin{tabular}{|c|c|c|c|c|}
\hline \multirow[b]{2}{*}{ Variables } & \multicolumn{3}{|c|}{ ADF TestsFirst Difference } & \multirow[b]{2}{*}{$\begin{array}{ll}\text { Order } & \text { of } \\
\text { Integration }\end{array}$} \\
\hline & $\begin{array}{ll}\text { Absolute } & \text { Test } \\
\text { Statistic } & \text { with } \\
\text { intercept } & \\
\end{array}$ & $\begin{array}{l}\text { Absolute } \\
\text { Critical } \\
\text { Values@ 5\% }\end{array}$ & Remark & \\
\hline MGDP & 3.1783 & 2.9640 & no unit root & $I(1)$ \\
\hline ACA & 6.4893 & 2.9604 & no unit root & $I(1)$ \\
\hline ACM & 3.7918 & 2.9640 & no unit root & $I(1)$ \\
\hline CBI & 5.9704 & 2.9604 & no unit root & $I(1)$ \\
\hline CBR & 4.5059 & 2.9862 & no unit root & $I(1)$ \\
\hline LR & & & & $I(0)$ \\
\hline LDR & & & & $I(0)$ \\
\hline EXR & 5.4115 & 2.9604 & no unit root & $I(1)$ \\
\hline
\end{tabular}

Source: Researcher's Computation

From Table 4.1 and 4.2, the results based on ADF tests show that commercial bank lending rate (LR) and loan-to-deposit ratio (LDR) were stationary at levels. Manufacturing sector performance (MGDP), aggregate credit to the manufacturing sector (ACM), Commercial Banks' reserve requirement (CBR), Commercial Banks' Investment (CBI), and EXR (Real effective Exchange Rate Index) were stationary at first difference, making them integrated of order one, that is I(1). It has been established by Pesaran, Shin and Smith (2001) that the bounds technique allows a mixture of $\mathrm{I}(1)$ and $\mathrm{I}(0)$ variables as regressors. Based on this ground, we proceed to perform the ARDL bounds test for cointegration.

Table 4.3: Cointegrating Equation and Long-run Model between Manufacturing Sector and non-correlated Banking Reform Variables.

Levels Equation

Case 3: Unrestricted Constant and No Trend

\begin{tabular}{lllll}
\hline \hline Variable & Coefficient & Std. Error & t-Statistic & Prob. \\
\hline \hline LNACM & $\mathbf{- 0 . 6 9 2 6 6 8}$ & 4.868419 & $\mathbf{- 0 . 1 4 2 2 7 8}$ & $\mathbf{0 . 8 8 8 3}$ \\
LNLDR & -35.36526 & 112.2988 & $\mathbf{- 0 . 3 1 4 9 2 1}$ & $\mathbf{0 . 7 5 6 1}$ \\
LNLR & $\mathbf{2 8 . 8 7 8 3 9}$ & $\mathbf{7 6 . 5 6 0 2 8}$ & $\mathbf{0 . 3 7 7 1 9 8}$ & $\mathbf{0 . 7 1 0 0}$ \\
\hline \hline
\end{tabular}

EC = LNMGDP - (-0.6927*LNACM $-35.3653 *$ LNLDR + 28.8784*LNLR )

\section{Source: Researcher's Computation}

Again, neither of commercial bank credit to the manufacturing sector, commercial bank loanto-deposit ratio or commercial bank lending rate had statistically significant relationship with manufacturing sector in the long-run. This is evidence by their corresponding $\mathrm{p}$-values at 0.883 , 0.7561 and 0.7100 , respectively in table 4.3 . Table 4.3 indicate the commercial bank credit to the manufacturing sector, with a coefficient of -0.6927 , has a negative relationship with manufacturing sector production in the long-run. The coefficient value of -0.6927 implies that a $1 \%$ change in commercial bank credit to the manufacturing sector results to $69.27 \%$ decrease in manufacturing sector growth. Similarly, commercial bank loan-to-deposit ratio has a 
negative relationship with manufacturing sector growth, indicated by the coefficient -35.3653 in the long-run. The coefficient value of -35.3653 implies that a $1 \%$ change in commercial bank loan-to-deposit ratio results to 3,5365.3\% decreases in manufacturing sector growth. Finally, commercial bank lending rate has a coefficient of 28.87839 with manufacturing sector growth, meaning that a $1 \%$ change in exchange rate leads to $2,887.84 \%$ increase in manufacturing sector growth.

Table 4.4: Cointegrating Equation and Long-run Model between Manufacturing Sector and correlated Banking Reform Variables.

\section{Levels Equation}

Case 3: Unrestricted Constant and No Trend

\begin{tabular}{|c|c|c|c|}
\hline Variable & $\begin{array}{l}\text { Coefficie } \\
\text { nt Std. Error }\end{array}$ & t-Statistic & Prob. \\
\hline LNCBI & 0.1804880 .106576 & 1.693506 & 0.1045 \\
\hline LNCBR & -0.1188680 .342478 & -0.347083 & 0.7318 \\
\hline LNEXR & 0.9135180 .632206 & 1.444969 & 0.1626 \\
\hline
\end{tabular}

\section{Source: Researcher's Computation}

Table 4.4 indicate the commercial bank investment (CBI) with a coefficient of 0.180488 , has a positive but non-significant relationship with growth of the manufacturing sector in the longrun, where $p$-value is 0.1045 . The coefficient value of 0.180488 implies that a $1 \%$ increase (decrease) in commercial bank investment results to about $18.05 \%$ increase (decrease) in growth of the manufacturing sector. In contrast, commercial bank reserve requirement (CBR) has a non-significant relationship with the growth of the manufacturing sector (where p-value is 0.7318 ), but this time around, the relationship is negative as indicated by the coefficient 0.118868 in the long-run. The coefficient value of -0.118868 implies that a $1 \%$ increase (decrease) in commercial bank reserve requirement results to about $11.89 \%$ decrease (increase) in the growth of the manufacturing sector. This effect is not statistically significant evidenced by the p-value of 0.7318 , which is above the significant level of 0.05 . Finally, exchange rate has a coefficient of 0.913518 with manufacturing sector growth, meaning that a $1 \%$ change in exchange rate leads to about $91.35 \%$ increase in manufacturing sector growth. This effect is also not statistically significant evidenced by the p-value of 0.1626 , which is above the significant level of 0.05 . 
International Journal of Business and Management Review

Vol.8, No.4, pp.11-38, July 2020

Published by ECRTD-UK

Print ISSN: 2052-6393(Print), Online ISSN: 2052-6407(Online)

Short-Run Model Estimation

Serial Correlation CM Test

Table 4.5: Manufacturing Sector Growth with Uncorrelated Banking Reform

Variables

Breusch-Godfrey Serial Correlation LM Test:

\begin{tabular}{llll}
\hline F-statistic & 0.319886 & Prob. F(2,18) & 0.7303 \\
Obs*R-squared & 1.029689 & Prob. Chi-Square(2) & 0.5976 \\
\hline \hline
\end{tabular}

Since the $p$-values of 0.7303 is considerably in excess of 0.05 , we conclude that there is no statistical evidence of serial correlation in the model involving manufacturing sector growth and uncorrelated banking reform variables.

Table 4.6: Manufacturing Sector Growth with Correlated Banking Reform Variables

Breusch-Godfrey Serial Correlation LM Test:

\begin{tabular}{llll}
\hline \hline F-statistic & 0.283922 & Prob. F(2,9) & 0.7593 \\
Obs*R-squared & 1.424382 & Prob. Chi-Square(2) & 0.4906 \\
\hline \hline
\end{tabular}

Since the $p$-values of 0.7593 is considerably in excess of 0.05 , we conclude that there is no statistical evidence of serial correlation in the model involving manufacturing sector growth and correlated banking reform variables.

\section{Heteroskedasticity Test}

Table 4.7: Manufacturing Sector Growth with Uncorrelated Banking Reform Variables

Heteroskedasticity Test: Breusch-Pagan-Godfrey

\begin{tabular}{lrll}
\hline \hline F-statistic & 1.680708 & Prob. F(9,20) & 0.1596 \\
Obs*R-squared & 12.91882 & Prob. Chi-Square(9) & 0.1663 \\
Scaled explained SS 7.892637 & Prob. Chi-Square(9) & 0.5450 \\
\hline \hline
\end{tabular}

Since the $p$-values of the F-statistic (p-value $=0.1596$ ) is considerably in excess of 0.05 , we conclude that there is no statistical evidence of the presence of Heteroskedasticity in the model involving manufacturing sector growth and uncorrelated banking reform variables. 
International Journal of Business and Management Review

Vol.8, No.4, pp.11-38, July 2020

Published by ECRTD-UK

Print ISSN: 2052-6393(Print), Online ISSN: 2052-6407(Online)

Table 4.8: Manufacturing Sector Growth with Correlated Banking Reform Variables

Heteroskedasticity Test: Breusch-Pagan-Godfrey

\begin{tabular}{lrll}
\hline \hline F-statistic & 0.563296 & Prob. F(12,11) & 0.8309 \\
Obs*R-squared & 9.134757 & Prob. Chi-Square(12) & 0.6914 \\
Scaled explained SS 1.867591 & Prob. Chi-Square(12) & 0.9996 \\
\hline \hline
\end{tabular}

Since the $p$-values of the F-statistic (p-value $=0.1446$ ) is considerably in excess of 0.05 , we conclude that there is no statistical evidence of the presence of Heteroskedasticity in the model involving manufacturing sector growth and correlated banking reform variables.

\section{DISCUSSION}

With all these findings, the study has posited that bank reforms are supposed to promote banking sector intermediation to support the economic wellbeing of businesses in Nigeria. This is borne out of the premise that reforms were to enhance the mobilization of deposits and more efficient resource allocation to promote economic growth, with the manufacturing sector being the surest route to the much desired economic growth. It was expected at the beginning of this work as indicated in the apriori expectation that bank reforms would cause a change in aggregate credit allocation, reserve requirements, loan-deposit-ratio, lending rates and banking investments for onward growth of the manufacturing sector. The results of analysis for the period 1986-2018 indicates that bank reforms have mainly unimpressive reports with respect to supporting growth of the manufacturing sectors. This shows a weak financial development in Nigeria. For finance to have any positive effect on the manufacturing sector and economic growth, the industry's regulators should make banks more responsible to this regard: channelling funds to the productive sector in an efficient manner.

In general, the growth of Nigerian banks is still miles away from being satisfactory to the manufacturing sector knowing very well that the sector posits itself as the "nucleus" of other economic activities. Effective policies for efficient resource allocation from banks to promote economic growth of the manufacturing sector and the economy at large should be prioritized by the $\mathrm{CBN}$ and government.

\section{Implication to Research and Practice}

The study was set out to find out the effect of banking reforms on the growth of manufacturing sector in Nigeria: 1986-2018. The study was specifically undertaken to assess the efficiency and effectiveness of the reforms initiated by the CBN and also to unravel in the reforms with regards to the growth of manufacturing sector in Nigeria. The dependent variables were manufacturing sector growth, indicated as MGDP. The independent variables were as follows: ACA (Aggregate credit to the agricultural sector as a proxy for Credit Operations Reforms), ACM (Aggregate credit to the manufacturing sector as a proxy for Credit Operations Reforms), CBR (Commercial Banks' reserve requirement as proxy for Capitalization and Capital Adequacy Reforms), CBI (Commercial Banks' Investment as proxy for corporate governance reform), LDR (Loan-to-deposits ratio as a proxy for Asset Quality Management Reforms), LR (Lending rate as a proxy for Liquidity Management Reforms), and EXR (Real effective Exchange Rate Index). 
The information obtained from the study indicated that $\mathrm{CBN}$ undertook various banking reforms as a measure to promote financial intermediation role of banks to the economy. From the review of related works and analysis of data, the following outcomes are summarized below:

Banking reforms did not have significant effect on growth of the manufacturing sector for the period 1986 to 2018.

\section{CONCLUSION}

Based on our findings, the following conclusions become necessary to curb or at least minimize the problems encountered by the banks in ensuring strict compliance with the flow of credit to the manufacturing sector by commercial banks. They include:

A More Structured Reform Programme that Prioritizes Credit to the manufacturing sector should be promoted. Banking reform should be well defined with identifiable and specific objectives that prioritize credit finance to the manufacturing sector.

Financial liberalization should be promoted by regulatory authorities for resource mobilization since it has proved potent in this regard. On the part of commercial banks, it is recommended that they develop products that induce longer term (longer maturities) deposit schemes. For any bank to effectively carter for any financing to the real sector and avert the problem of maturity mismatch, longer maturity savings plans should be introduced with greater incentives to intending savers. The prevailing huge degree of demand deposit with respect to total deposit base is not sustainable for credit for investment purpose.

Since financial liberalization has not favoured credit finance to the manufacturing sector because of Nigeria's unique economic complexities, financing control should be pursued in favour of credit flow to the manufacturing sector.

As a matter of policy framework, the CBN should prioritize macroeconomic stability and adequate regulatory framework before embarking on liberalization.

\section{Future Research}

The findings of this research have unravelled many novel issues regarding the conception and administration of banking reform policies to achieve growth for the manufacturing sector in Nigeria. These novelties have been exhaustively discussed. There is, however, a key area of transmission of banking reform policies to achieve growths of manufacturing sector capital formation and depositor confidence which was considered too broad to be considered as one of the specific objectives for this study.

However, considering the effect of capital formation on economic growth for resource-rich countries like Nigeria with different capabilities for managing macroeconomic policies to achieve economic growth, an analysis of capital formation and depositor confidence should be done on the growth of the of the manufacturing sector in Nigeria. Specific country peculiarities will also be explored and the dynamics of transmitting banking reforms to achieve economic growth through capital formation will be examined with a view to revealing economic growth prospects to be achieved in Nigeria using other country model.

\section{REFERENCES}

Abata, M.A., (2014). Asset Quality and Bank Performance: A Study of Commercial Banks in Nigeria. Research Journal of Finance and Accounting,5(18), 39-44. 
International Journal of Business and Management Review

Vol.8, No.4, pp.11-38, July 2020

Published by ECRTD-UK

Print ISSN: 2052-6393(Print), Online ISSN: 2052-6407(Online)

Abiodun, E.A. \& Victor, E.O. (2014). An Empirical Assessment of Banking Sector Reform and Unemployment in Nigeria, 6(3), 35-48.

Adesanya, B. \& Obademi, O. E (2016). Banking Sector Reforms and Economic Growth: Evidence from Nigeria.International Journal of Social Science and Economic Research, 1(10), 1705-1717.

Aiyetan, I.R \& Aremo A.G. (2015). Effect of Financial Sector Development on Manufacturing Output Growth in Nigeria (1986-2012): A Vector Auto Regression Approach.Journal of Applied Economics and Business Research JAEBR, 5(1), 38-55.

Akinmulegun, S.O. and Oluwole, F.O. (2014). An Assessment of the Nigerian Manufacturing Sector in the Era of Globalization. American Journal of Social and Management Sciences, 5(1), 27-32.

Ali, J.I. (2015). Effect of Banking Sector Reforms on the Performance of Deposit Money Banks' in Nigeria. A Thesis Submitted to the Department of Banking and Finance University of Agriculture Makurdi.

Ali, U.I. (2006). Term Structure of Interest Rates. Survey submitted to the Economics Department of the University of California, Santa Barbara in fulfillment of the requirement for M.A. Theory of Finance.

Anyanwu C.M.(2010). An Overview of Current Banking Sector Reforms and the Real Sector of the Nigerian Economy Central Bank of Nigeria.Economic and Financial Review, 48(4),51-56.

Asekome, M.O. \& Aihie J.A. (2014). Challenges of Banking Sector Reforms in Nigeria: An Appraisal. International Journal of Business and Social Science, 7(1), 224-230.

Bada, O.T. (2017). The Effect of Banks' Credits on the Development of Manufacturing and Agricultural Sectors of Nigeria's Economy. International journal of advanced studies in economics and public sector management, 5(1), 114-130.

Balogun, E. D. (2007). "Banking Sector Reforms and the Nigerian Economy: Growth, Pitfalls and Future Policy Options". Munich Personal RePEc Archive MPRA Paper No.3804. http://mpra.ub.uni-muenchen.de/3804 : : 1-26

Campbell, O. \& Asaleye, A.J. (2016). Financial Sector Reforms and Output Growth in Manufacturing: Empirical Evidence from Nigeria. American International Journal of Contemporary Research, 6(3), 112-125.

CBN, (2006). Code of corporate governance for banks in Nigeria post consolidation.

CBN, (2012). Banking reform and its impact on the Nigerian economy: Being a lecture delivered by Sanusi Lamido Sanusi CBN Governor. University of Warwick's Economic Summit. UK: Research Department of the Central Bank of Nigeria.

CBN, (2018). Statistical Bulletin. Abuja: Central Bank of Nigeria.

Coert, E. \& Daniel, M. (2014). An Empirical Study of Bank Efficiency in South Africa Using the Standard and Alternative Approaches to Data Envelopment Analysis.Journal of Economics and Behavioral Studies, 6(4), 310-317

Dada, O.D. (2015). Effect of Financial Sector Reforms on the Growth of Manufacturing Sector in Nigeria. International Journal of Banking, Finance, Management \& Development Studies,3(1), 12-20.

Ebele, E.J.\& Iorember P.T. (2016). Commercial Bank Credit and Manufacturing Sector Output In Nigeria.Journal of Economics and Sustainable Development $\underline{\mathrm{Www} . I i s t e . O r g}$ (Online) (7)16.

Evelyn, N. O. (2010). Banking Sector Reforms and the Industrial Sector: The Bank of Industry Experience Central Bank of Nigeria Economic and Financial Review,48(4), 67-76. 
Frank, I.O. \& Rotimi, J. (2016). Can Financial Reform Drive Manufacturing Sector Performance? Evidence From a Developing Economy.JORIND, 14(2),1-11

Hanumanthappa K. M. (2014). A Clarification of the Concept of Agricultural Productivity in Karnataka, International Journal Innovative Research and Development, (3)7, 395-397

Jhingan, M. L. (2004). Monetary Economics (6th Ed.). New Delhi, India: Vrinda Publications Ltd.

Jide A. M. (2010). Banking Sector Reforms and the Manufacturing Sector: The Manufacturers' Association of Nigeria Perspective. Central Bank of Nigeria Economic and Financial Review, 46(4), 57-65

Lucky, U. \& Bruno, O.O.(2018).Banking Sector Reforms and the Performance of BankingBusiness in Nigeria. An Econometric Analysis.International Journal of Business and Management review. 6(6), 40-45.

Nzotta, S. M. (2014). Money, Banking and Finance: Theory and Practice, Revised Edition, Hudson-Jude Nigeria Publisher Owerri; Imo State.

Ogar, A. Nkamare, S.E. \& Charles, E. (2014).Commercial Bank Credit and Its Contributions on Manufacturing Sector In Nigeria.Research Journal of Finance and Accounting, (5) $22,188-196$.

Okafor F.O. (2011). 50 Years of Banking Sector Reforms in Nigeria (1960 - 2011): Past Lessons - Future Imperatives. Enugu: Ezu Books Ltd.

Okonkwo, N. O. \& Bankoli, B. (2016). Banking Sector Reform and the Nigerian Economy: An Appraisal. International Journal of Innovative Finance and Economics Research 4(1),13-18.

Sani U. G, \& Ali J.I. (2017). Effect of Corporate Governance on Asset Quality: Performance Evaluation of the Nigerian Banking Sector in the Post Consolidation Era. International Journal of Accounting, Finance and Risk Management. 2(1), 1-9.

Sanusi, L. S. (2012). Banking Reform and Its Impact on the Nigerian Economy, Lecture delivered at the University of Warwick's Economic Summit, UK, 17th February.

Yua, H. (2017). Effect of Deposit Money Banks' Credit on the Manufacturing Output in Nigeria. M.sc thesis submitted to the department of Accounting and Finance university of Agriculture Makurdi.

Yua, H, Jocelyn, U.U, Adiga, D.L \& Haruna, H.A (2020) Commercial Bank Credit and Manufacturing Sector

Performance in Emerging Economies: Evidence from Nigeria, The International Journal Of Business Management 8(5) 155-161 